\title{
DESKRIPSI LINGKUNGAN AGRIBISNIS PERDESAAN DI KECAMATAN SORONG TIMUR KOTA SORONG
}

\author{
Margareta Evin Arne \\ Ventje V. Rantung \\ Jenny Baroleh \\ Jean Fanny Juanita Timban
}

\begin{abstract}
Subdistrict East Sorong is producing areas of agricultural products with the highest commodities compared to other areas in the city of Sorong. Kelurahan Klamana and Klawalu are two areas in the district of East Sorong has run rural agribusiness and is a village that has the largest population who are farmers, especially farmers horticulture. The aim of research to determine the circumstances: 1) agriculture, business or field of business, agribusiness perdesan in District East Sorong Sorong City, and 2) farm in the district of East Sorong. This research was conducted in the Eastern District of Sorong Sorong City began in October to December 2014. This study is using the survey method. Retrieval of data are primary data and secondary data. Data were analyzed using descriptive. Results of the study portrait of the general state of agriculture and business, the business field of agriculture, infrastructure support in the district of East Sorong Sorong.
\end{abstract}

Keywords: horticulture, supporting infrastructure, East Sorong

\begin{abstract}
ABSTRAK
Kecamatan Sorong Timur adalah daerah penghasil produk pertanian dengan jenis komoditas terbanyak dibandingkan dengan daerah lain di Kota Sorong. Kelurahan Klamana dan Klawalu merupakan dua daerah di Kecamatan Sorong Timur telah menjalankan agribisnis perdesaan dan merupakan Kelurahan yang memiliki penduduk terbesar yang bermata pencaharian sebagai petani khususnya petani holtikultura. Tujuan penelitian untuk mengetahui keadaan: 1) pertanian, bisnis atau lapangan usaha, agribisnis perdesan di Kecamatan Sorong Timur Kota Sorong, dan 2) pertanian di Kecamatan Sorong Timur. Penelitian ini dilaksanakan di Kecamatan Sorong Timur Kota Sorong mulai pada bulan, Oktober sampai Desember 2014. Penelitian ini adalah menggunakan metode survey. Pengambilan data yaitu data primer dan data sekunder. Teknik analisis data menggunakan deskriptif. Hasil penelitian mengambarkan keadaan umum dari pertanian dan bisnis, lapangan usaha pertanian, infrastuktur penunjang di Kecamatan Sorong Timur Kota Sornn
\end{abstract}

Kata Kunci: holtikultura, infrastruktur penunjang, Sorong Timur

\section{PENDAHULUAN}

\section{Latar Belakang}

Pengembangan kawasan perdesaan di Indonesia akan semakin menantang di masa depan dengan kondisi perekonomian daerah yang semakin terbuka dan kehidupan berpolitik yang lebih demokratis. Akan tetapi desa sampai sekarang ini belum beranjak dari profil lama yakni keterbelakang dan miskin. Meskipun banyak pihak mengakui bahwa desa mempunyai peranan yang besar bagi kota, namun desa tetap saja masih dipandang rendah dalam hal ekonomi atau pun lainnya. Padahal kita ketahui bahwa sebagian penduduk indonesia berdiam di daerah perdesaan dan berprofesi sebagai petani kecil (lahan terbatas 
atau sempit). Oleh karena itu, sudah sewajarnya bila pembangunan perdesaan harus menjadi prioritas utama dalam segenap rencana strategi dan kebijakan pembangunan di Indonesia. Jika tidak, maka jurang pemisah antara kota dan desa akan semakin tinggi terutama dalam hal perekonomian (Bapenas, 2005).

Menurut undang-undang No.26 Tahun 2007 tentang penataan ruang didefenisikan kawasan perdesaan adalah wilayah yang mempunyai kegiatan utama pertanian, termasuk pengelolaan sumberdaya alam dengan susunan fungsi kawasan sebagai tempat pemukiman perdesaan, pelayanan jasa pemerintahan, pelayanan sosial, dan kegiatan ekonomi. Kata kawasan sendiri dapat diartikan sebagai wilayah dengan fungsi utama adalah lindung atau budidaya, sedangkan wilayah adalah ruang yang merupakan kesatuan geografis beserta segenap unsur terkait pada yang batas sistemnya di tentukan berdasarkan aspek administratif dan aspek funsional.

Pengembangan wilayah pada kawasan perdesaan harus di pandang sebagai bagian yang tak terpisahkan dengan kawasan perkotaan. Pemahaman yang menyeluruh ini menjadi penting dan mendasar dalam penyusunan peraturan atau aturan main yang berkaitan dengan perdesaan maupun perkotaan, agar terjadi sinergi dan keseimbangan perilaku wilayah, khususnya pelaku pembangunan. (Rahardjo, 2007).

Hal ini tercermin dari rendahnya produktivitas pertanian dan masyarakat pertanian, tingginya jumlah masyarakat pertanian yang miskin dan rendahnya nilai tamba pertanian dan pangan yang dinikmati masyarakat pertanian. Kedepan pengembangan pertanian dan pangan diorentasikan pada upaya peningkatan pendapatan dan kesejahtraan masyarakat pertanian. Untuk itu program-program pengembangan pertanian dan pangan dikosentrasikan pada peningkatan produktivitas pertanian dan masyarakat pertanian khususnya petani kecil, dan mengatasi kemiskinan, dan meningkatkan nilai tambah pertanian dan pangan bagi masyarakat pertanian melalui peningkatan hubungan industri antara pertanian, pangan dan sektor-sektor pertanian lainnya.

Pengembangan program pertanian dan pangan dilakukan melalui proses pengembangan pertanian dan pangan yang di integrasikan dengan pegembangan masyarakat, pengembangan perdesaan dan wilayah dan pembangunan nasional secara holistik. Untuk pengembangan pertanian dan pangan akan di hubungkan penuh dengan seluruh sektor dan aktivitas ekonomi pendukungnya, termasuk di dalamnya pengairan, sistem perkreditan, penelitian dan pengembangan teknologi dan informasi, serta kelembagaan masyakat pertanian dan pangan berbagai sektor dan aktivitas pembangunan ekonomi tersebut dalam kerangka program agrobisnis dan ketahanan pangan. Pengembangan pertanian ketahanan pangan dan stabilitas perdesaan akan memperoleh perhatian khusus karena sektor pertanian dan pangan di perdesaan merupakan sektor ekonomi yang berdiri sendiri dan berfungsi multisektoral.

Program pengembangan agribisnis, menurut Rahardjo (2007), mempunyai lima sasaran utama yaitu:

1. Meningkatkan produktivitas, kualitas dan komoditas unggulan tanaman pangan, holtikultura, peternakan, perikanan, perkebunan dan kehutanan.

2. Meningkatkan kesempatan kerja dan berusaha di perdesaan.

3. Meningkatkan nilai tambah bagi masyarakat pertanian, perikanan, perkebunan, peternakan dan kehutanan.

4. Meningkatkan nilai tambah bagi masyarakat dan investasi swasta dalam pembagunan pertanian dan perdesaan.

5. Terpeliharanya sumberdaya alam dan lingkungan

Kota Sorong adalah salah satu ibu kota madya di Provinsi Papua Barat yang letaknya yang sangat strategis karena merupakan pintu keluar masuk Papua serta kota persinggahan dan memiliki kekayaan alam yang berlimpah pada sektor perikanan, kelautan dan sektor pertanian dan hasil bumi berupan minyak dan gas bumi .

Kecamatan Sorong Timur dengan luas wilayah 158, 16 km2. Wilayah Kecamatan Sorong Timur potensi sumberdaya lahan untuk pengembangan usaha pertanian yaitu palawija dan holtikultura dan lahan perkebunaan peternakan dan perikanan. Adapun pengunaan lahan sebagai hutan rakyat dan hutan lindung. 
Pengembangan kawasan perdesaan difokuskan pada lokasi yang memiliki potensi sumberdaya alam yang dapat ditingkatkan nilai tambahnya, sumberdaya manusia terampil dan infrastruktur wilayah yang memadai guna mendukung investasi yang berbasis pada potensi ekonomi lokal.

\section{Perumusan Masalah}

Berdasarkan latar belakang yang telah di uraikan tentang deskripsi lingkungan agribisnis perdesaan di Kecamatan Sorong Timur Kota Sorong, maka yang menjadi masalah adalah:

1. Apa yang menjadi kendala dalam usaha pertanian

2. Apakah Kecamatan Sorong Timur mempunyai usaha dalam agribisnis perdesaan?

\section{Tujuan}

1. Untuk mendeskripsikan keadaan pertanian dan bisnis Kecamatan Sorong Timur

2. Untuk mendeskripsikan agribisnis perdesaan di Kecamatan Sorong Timur

\section{Manfaat penelitian}

1. Memberikan informasi mengenai deskripsi lingkungan agribisnis di Kecamatan Sorong Timur Kota Sorong

2. Melalui penelitian ini dapat diketahui deskripsi lingkungan agribisnis mana yang lebih besar dan maju

\section{METODOLOGI PENELITIAN}

Waktu dan Tempat Penelitian

Penelitian ini dilaksanakan pada bulan OktoberDesember 2014 Kecamatan Sorong Timur Kota Sorong.

\section{Metode Pengumpulan Data}

Data yang digunanakan dalam penelitian ini adalah data primer dan data sekunder. Data primer di peroleh dari wawancara langsung kepada pemerintah setempat terutama Kepala Desa, petani yang mengetahui keadaan secara umum.
Sedangkan data sekunder di peroleh melalui kantor Camat, Kantor lurah, Badan Pusat Statistik, Badan Perencanaan dan Pengembangan Daerah, dan Literarur Kepustakaan yang ada hubungannya dengan penelitian ini.

\section{Metode pengambilan Sampel}

Metode pengambilan sampel menggunakan metode "purposive sampling" yaitu teknik pengambilan sampel dengan tujuan menggunakan 2 desa di Kecamatan Sorong Timur 2 Lurah yaitu, Kelurahan Klawalu dan Klamana, 10 Orang petani sebagai pengambilan sampel

Kelurahan Klawalu dan Kelurahan Klamana merupakan pusat pertanian dan peternakan di Kecamatan Sorong Timur Kota sorong dengan ini maka kami dapat memilih dua kelurahan ini sebagai tempat atau wilayah pengambilan sampel.

\section{Konsep Pengukuran Variabel}

Variabel-Variabel yang dilakukan dalam penelitian ini meliputi :

1. Komoditi pertanian dan luas lahan, produksi, kegiatan pertanian

2. Pendidikan Petani, umur

3. Bisnis dan lapangan usaha

\section{Metode Analisis Data}

Teknik analisis data dalam penelitian ini adalah menggunakan metode deskriptif.

\section{HASIL DAN PEMBAHASAN}

\section{Deskripsi Wilayah Penelitian Kecamatan Sorong Timur}

\section{Letak dan Luas Wilayah}

Kecamatan Sorong Timur adalah merupakan salah satu kecamatan yang ada di Kota Sorong. Terletak pada posisi yang sangat strategis dan merupakan Daerah perdadangan dan kawasan yang potensial untuk pengembangan pertanian dan peternakan.

Kecamatan Sorong Timur mempunyai luas wilayah keseluruhan $158,71 \mathrm{~km} 2$ yang terdiri dari 7 kelurahan. Adapun batas-batas wilayah kecamatan Sorong Timur ini adalah : 
- Sebelah Utara berbatasan dengan Kecamatan Sorong Utara

- Sebelah Timur berbatasan dengan Kecamatan Klaurung

- Sebelah Selatan berbatasan dengan Selat Dokarim

- Sebelah Barat berbatasan dengan Kecamatan Manoi

Sedangkan topografi untuk Kecamatan berfariasi terdiri atas pegunungan, lereng, bukit, sebelah Timur dan selatan pada umumnya dataran rendah dengan ketinggian antara 0-5 meter diatas permukaan laut.

\section{Kebudayaan Sosial Budaya}

Penduduk di Kecamatan Sorong Timur terdiri dari berbagai macam agama yaitu agama Kristen Protestan, Kristen Katolik, Islam, Hindu, Budha.

\section{Penduduk}

Jumlah penduduk kecamtan Sorong Timur adalah 30.032 jiwa terdiri dari: Laki - laki 14.457 Orang dan Perempuan 15.575 Orang.

\section{Mata Pencaharian}

Jumlah penduduk di Kantor Kecamatan Sorong Timur sampai akhir tahun 2012 sebagian besar adalah bermata pencaharian sebagai petani, pegawai negeri, sector jasa, pedagang, pegawai swasta, dan pensiunan. Tabel 1 menunjukan bahwa sebagian besar mata pencaharian adalah petani sebesar 29.3 persen atau 376 jiwa. Kemudian menyusul pegawai negeri sipil 16 persen atau 206 jiwa, dan paling sedikit jasa pengobatan 0.9 persen atau 12 jiwa.

\section{Keadaan Pertanian}

Tanaman pertanian pangan dan holtikultura, luas tanaman jagung, umbi-umbian dan kacang tanah seluas $118.6 \mathrm{Ha}$ (Tabel 2). Komoditi pertanian tanaman pangan dan holtikultura di Kecamatan Sorong Timur tersebar di beberapa wilayah atau kelurahan terdekat.
Tabel 1. Jenis Mata pencaharian Penduduk di Kecamatan Sorong Timur

\begin{tabular}{llll}
\hline No & \multicolumn{1}{c}{$\begin{array}{c}\text { Jenis } \\
\text { Mata } \\
\text { Pencaharian }\end{array}$} & Jumlah & $\begin{array}{c}\text { Presentase } \\
(\%)\end{array}$ \\
\hline 1 & Petani & 376 & 29.3 \\
2 & Buruh Tani & 152 & 12 \\
3 & PNS & 206 & 16 \\
4 & TNI \& Polri & 152 & 1.8 \\
5 & Pengusaha & 120 & 9.3 \\
6 & Kecil & 46 & 3.6 \\
7 & Karyawan & 12 & 0.9 \\
8 & Swasta & 24 & 1.9 \\
9 & Jasa & 118 & 9.2 \\
10 & Sopir & 56 & 4.4 \\
11 & Peternak & 23 & 1.8 \\
12 & Ketrampilan & & \\
13 & Monitor & \multicolumn{3}{l}{100} \\
\hline \multicolumn{4}{l}{ Jumlah } \\
\hline
\end{tabular}

Secara administratif Kecamatan Sorong Timur merupakan bagian dari Kabupaten kota Sorong memiliki potensi sumberdaya alam yang cukup menjanjikan bagi masyarakat yang ada diwilayahnya serta beragamnya jenis komoditas pertanian tanaman pangan, dan perkebunan yang sudah sejak lama diusahakan sebagai sumber pangan dan pendapatan masyarakat khususnya petani. Keberadaan lahan pertanian dan pangan, juga memegang peranan penting dalam penyediaan pangan.

Pembangunan sektor pertanian di Kecamatan Sorong Timur sampai dengan tahun 2012 ini semakin menunjukan peningkatan yang cukup baik. Hal ini tentu saja tidak terlepas dari peran seluruh pihak yang terkait dalam pertanian untuk mewujudkan pembangunan pertanian yang berdampak pada meningkatnya kesejahteraan petani dan dapat menurunkan angka kemiskinan di Kecamatan Sorong Timur khususnya. Indikator utama keberhasilan pembangunan pertanian pada umumnya dapat terlihat dengan adanya peningkatan produksi hasil pertanian. 
Tabel 2. Luas lahan untuk Komoditi Pertanian Kecamatan Sorong Timur 2012

\begin{tabular}{llll}
\hline No & Jenis Komoditi & $\begin{array}{l}\text { Luas } \\
(\mathrm{Ha})\end{array}$ & Presentase \\
\hline 1 & Holtikultura & $\mathbf{1 0 3}$ & $\mathbf{3 4 , 6 2}$ \\
2 & Jagung & $\mathbf{1 4 , 5}$ & $\mathbf{4 , 8 7}$ \\
3 & Ubi Kayu & $\mathbf{0 , 5}$ & $\mathbf{0 , 1 7}$ \\
4 & Ubi Jalar & $\mathbf{0 , 4}$ & $\mathbf{0 , 1 3}$ \\
5 & Kacang Tanah & $\mathbf{0 , 2}$ & $\mathbf{0 , 0 8}$ \\
\hline & Total & $\mathbf{1 1 8 . 6}$ & $\mathbf{3 9 , 8 7}$
\end{tabular}

\section{Sumber : Kantor Kecamatan Sorong Timur}

\section{Tanaman Pertanian di Kecamatan Sorong Timur}

Selama tahun 2005 sampai 2012 capaian produksi untuk komoditas unggulan pertanian di Kecamatan Sorong Timur telah menunjukan prestasi yang baik walaupun setiap tahunnya mengalami fluktuasi antara lain:

1. Jagung pada tahun 2012 dengan luas panen 1730 ha dan mencapai produksi 8650 ton .

2. Holtikultura dengan luas areal mencapai 376 ha, tetapi yang dimanfaatkan secara intensif seluas 323 hektar. Ini berarti peluang pengembangan lahan pertanian terus meningkat. Dimana capaian produksi pada tahun 2011 mencapai 1938 ton menjadi 2261 ton tahun 2012 atau mengalami peningkatan.

3. Ubi kayu denga luas panen 39 ha dan mencapai produksi 327 ton.

4. Ubi jalar dengan luas panen 16 ha dan produksi mencapai 137 ton.

5. Kacang tanah dengan luas panen 506 ha dan mencapai produksi 642 ton. Selanjutnya dapat dilihat pada Tabel 2.

Tabel 3 menunjukkan bahwa komoditi holtikultura yang dominan dibandingkan dengan komoditas lainnya, karena para petani holtikultura di Kecamatan ini selain memiliki komoditas kelapa, juga memanfaatkan lahan yang kosong disetiap antara tanaman kelapa untuk ditanami holtikultura, sehingga luas panen holtikultura lebih tinggi dan produksinya pun lebih banyak yaitu mencapai produksi 120 ton dengan persentase 61,00 \% dengan luas areal 30 ha. Sedangkan jenis komoditas yang terendah adalah cabai yaitu hanya mencapai 1,5 ton dengan persentase $0,76 \%$ luas panen 2 ha. Hal ini disebabkan lahan cabai umumnya berada dilereng pegunungan, sehingga apabila hujan lebat turun maka tanaman tersebut akan terbawa longsoran tanah dan mengakibatkan produksi Kacang tanah berkurang.

Tabel 3. Keadaan Pertanian Kecamatan Sorong Timur Tahun 2012

\begin{tabular}{lllll}
\hline $\begin{array}{l}\text { Jenis } \\
\text { Komodita } \\
\text { s }\end{array}$ & $\begin{array}{l}\text { Luas } \\
\text { Pane } \\
\text { n } \\
(\text { Ha) }\end{array}$ & $\begin{array}{l}\text { Presenta } \\
\text { se (\%) }\end{array}$ & $\begin{array}{l}\text { Produk } \\
\text { si (Ton) }\end{array}$ & $\begin{array}{l}\text { Presenta } \\
\text { se (\%) }\end{array}$ \\
\hline Holtikultu & 30 & 35,71 & 120 & 61,00 \\
ra & 28 & 33,33 & 36,4 & 18,50 \\
Jagung & 17 & 20,23 & 34 & 17,28 \\
Ubi Jalar & 7 & 8,33 & 4,8 & 2,44 \\
Ubi Kayu & 2 & 2,38 & 1,5 & 0,76 \\
$\begin{array}{l}\text { Kacang } \\
\text { Tanah }\end{array}$ & & & & \\
\hline & $\mathbf{8 4}$ & $\mathbf{1 0 0}$ & $\mathbf{1 9 6 7}$ & $\mathbf{1 0 0}$ \\
\hline
\end{tabular}

Sumber : Kantor Kecamatan Sorong Timur

\section{Saluran pemasaran Komoditi Pertanian}

Saluran pemasaran komiditi pertanian adalah rangkaian lembaga-lembaga pemasran yang dilalui barang dalam penyaluran dari produsen ke konsumen. Penyaluran hasil produksi dari produsen ke konsumen melalui lebih dari satu saluran pemasaran dimana masing-masing saluran melibatkan lembaga pemasaran yang tidak sama.

Kegiatan dimana produsen dan konsumen yang merupakan komponen utama yang perlu di hubungkan satu dengan yang lain. Berdasarkan hasil penelitian di kecamatan Sorong Timur di peroleh saluran pemasaran komoditi pertanian sebagai berikut : 
1. Petani

2. Petani

pedagang pengumpul

pedagangencer

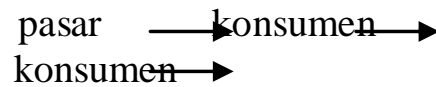

Keterangan :

1. Petani atau produsen menjual ke pedagang pengumpul kemudian pedagan pengumpul menjual ke pasar dan pedagan pasar menjualkan kepada konsumen atau pemakai yang membutuhkanya.

2. Petani menjual kepada pedagang pengencer dan pedagang pengencer menjual kepada konsumen atau pemakai.

\section{Pupuk}

Para petani di kecamatan Sorong Timur dalam berusaha tani menggunakan pupuk tetapi jarang menggunakan pestisida.Pupuk yang digunakan para petani yaitu pupuk kandang.

\section{Koperasi}

Koperasi dapat mendukung pengembangan agribisnis perdesaan di kecamatan Sorong Timur. Koperasi di kecamatan sorong terdiri dari: KUD Mandiri, KUD Klasaman. Koperasi dapat menunjang kesejahteraan dan kebutuhan masyarakat perdesaan dalam pengembangan agribisnis perdesaan di suatu wilayah berupa peminjaman uang untuk dapat mengatasi masalah.

\section{Listrik}

PLN yang terdapat di Kecamatan Sorong Timur adalah PLN Ranting dari Kota Sorong, dimana penyediaan mesin-mesin pembangkit berasal dari kantor PLN diKota Sorong. Data yang diperoleh dari PLN Ranting Sorong Timur terbatas pada data kapasitas yang terpasang, kemampuan mesin, jumlah listrik yang diproduksi, jumlah listrik yang terjual, banyaknya pelanggan, daya tersambung dan banyaknya penjualan listrik. Sedangkan untuk data distribusi penjualan listrik di PLN Ranting Sorong Timur datanya langsung dilaporkan ke kantor PLN di Kota Sorong, sehingga untuk data tersebut belum diperoleh. Data mengenai jumlah listrik yang terjual adalah banyaknya listrik yang disalurkan kepada para pelanggan. Sedangkan untuk data banyaknya unit, kapasitas terpasang, kemampuan mesin dan beban puncak dirinci menurut lokasi.

\section{Air Minum}

Perusahaan Daerah Air Minum (PDAM) adalah perusahaan yang mempunyai aktivitas dalam penampungan, penjernihan, dan penyaluran air baku atau air bersih dari terminal air melalui saluran air, pipa atau mobil tangki (dalam satu pengelolaan administrasi dengan kegiatan ekonomi) kepada rumah tangga, perusahaan industri, atau pengguna komersial lainnya.

Di Kecamatan Sorong Timur pada khususnya hanya terdapat satu PDAM yang penyaluran airnya hanya terbatas pada Kelurahan Kota saja (saluran air dengan pipa), sehingga diluar dari kelurahan tersebut masyarakat menggunakan airsumur maupun tadah hujan bagi keperluan sehari-sehari. Akan tetapi untuk untuk pelanggan dengan kategori tertentu menggunakan jasa mobil tangki milik PDAM, seperti hotel, instansi pemerintah, maupun rumah tangga bisnis.

\section{DESKRIPSI UMUM DUA KELURAHAN SAMPEL}

\section{Deskripsi Kelurahan Klamana}

Desa atau Kelurahan Klamana merupakan salah satu desa atau kelurahan di Kecamatan Sorong Timur dengan batas - batas Wilayah sebagai berikut :

$\checkmark$ Sebelah Utara Berbatasan dengan Kecamatan Sorong Utara

$\checkmark$ Sebelah Timur Berbatasan dengan Kelurahan Klasaman

$\checkmark$ Sebelah Selatan Berbatasan dengan

$\checkmark$ Sebelah Barat Berbatasan dengan

Desa atau Kelurahan Klamana mempunyai luas wilayah $24,23 \mathrm{~km} 2$ 


\section{Penduduk}

Penduduk di desa atau kelurahan Klamana adalah 9.710 jiwa yang terdiri dari : laki-laki 5.088 orang dan perempuan 4.622 orang

\section{Mata Pencaharian}

Umumnya mata pencaharian penduduk desa atau kelurahan Klamana adalah bersumber pada hasilhasil pertanian, namun ada juga yang bermata pencaharian sebagai pegawai dan pedagang. Data

Produksi Komoditi pertanian di Kelurahan holtikultura $30 \mathrm{~kg} / \mathrm{Ha}$ dan jagung $320 \mathrm{~kg} / \mathrm{Ha}$.

\section{Deskripsi Kelurahan Klawalu}

Kelurahan Klawalu terletak di ruas jalan Sorong -Maybrat kelurahan ini memiliki batas- batas wilayah sebagai berikut :

$\checkmark$ Sebelah Utara berbatasan dengan Kelurahan Klawuyuk

$\checkmark$ Sebelah Selatan Berbatasan dengan Laut

$\checkmark$ Sebelah Timur berbtasan dengan Kelurahan Klamana

$\checkmark$ Sebelah Barat berbatsan dengan Kelurahan Kladufu

Klawalu memiliki luas wilayah sebesar 19,16 km2.

\section{Penduduk}

Jumlah penduduk Kelurahan Klawalu adalah 4,836 jiwa yang terdiri dari Laki-laki 2,562 orang dan Perempuan 2,274 orang

\section{Mata Pencaharian}

Umumnya mata pencaharian penduduk desa atau kelurahan Klawalu adalah bersumber dari hasilhasil pertanian khususnya holtikultura. Penduduk yang bermata pencaharian sebagai petani sebagian besar $60 \%$ dan sisanya sebesar $40 \%$ adalah pegawai negeri sipil, dan Swasta.

\section{Karakteristik Petani}

Umur Petani
Umur petani akan mempengaruhi produktivitas
dalam bekerja atau peranan dalam pengambilan
keputusan dari berbagai alternatif pekerjaan yang
dilakukannya. Umur mempunyai hubungan dengan
kemampuan bekerja dan prestasi kerja. Secara

umum dapat dikatakan bahwa makin tinggi umur seseorang setelah melewati batas umur tertentu maka makin kurang kemampuan berprestasi sebagai tenaga kerja. Semakin bertambahnya usia petani maka semakin bertambah luas pengalaman dan wawasan dalam pengembangan kawasan.

Dari 10 responden yang diambil di kelurahan Klamana dan Klawalu menunjukan bahwa kisaran umur responden adalah 43-74 tahun. Untuk jelasnya dapat dilihat pada Tabel 5 .

Pada tabel 4 menunjukan bahwa kelompok umur 43-50 tahun adalah yang terbesar jumlahnya yaitu 4 petani atau 40 persen dari 10 petani responden yang diambil, kemudian diikuti kelompok umur 5158 tahun berjumlah 3 petani atau 30 persen dari 10 petani responden, sedangkan kelompok umur 59-66 tahun berjumlah 2 petani atau 20 persen dari 10 petani responden dan 1 petani untuk umur 67-74 tahun dengan persentase 10 persen dari jumlah responden.

Jumlah petani responden yang berumur 43-58 tahun adalah $70 \%$ sehingga dapat dikatakan bahwa sampel petani responden yang terbesar adalah petani-petani usia produktif.

\section{Tingkat Pendidikan}

Pendidikan merupakan faktor yang menentukan produktivitas tenaga kerja dimana pendidikan sebagai modal bagi petani dalam mengolah usahatani, karena pendidikan akan mempengaruhi cara berpikr petani. Pendidikan yang relatif tinggi akan menyebapkan petani lebih dinamis, sedangkan petani yang berpendidikan relatif rendah akan bersifat statis. Dengan semakin tinggi tingkat pendidikan akan menghasilkan cara berfikir yang lebih tinggi. Dalam hal ini petani bisa mempelajari tentang cara-cara pemasaran, pendidikan juga bukan pendidikan formal tapi juga non formal, seperti mengikuti seminar atau penyuluhan tentang pertanian. Tingkat pendidikan juga ditunjang dengan bakat dan kemauan. Selanjutnya untuk melihat pendidikan petani di Kecamatan Sorong Timur dapat dilihat pada Tabel 6. 
Tabel 5. Tingkat Pendidikan Petani Responden di Kecamatan Sorong Timur

\begin{tabular}{lll}
\hline $\begin{array}{l}\text { Tigkat } \\
\text { Pendidikan }\end{array}$ & $\begin{array}{l}\text { Jumlah } \\
\text { Petani Responden } \\
\text { (Orang) }\end{array}$ & $\begin{array}{l}\text { Presentase } \\
(\boldsymbol{\%})\end{array}$ \\
\hline SD & 5 & 50 \\
SMP & 2 & 20 \\
SMU & 3 & 30 \\
\hline Jumlah & $\mathbf{1 0}$ & $\mathbf{1 0 0}$ \\
\hline
\end{tabular}

Sumber : Diolah dari data Primer2014

Dari Tabel 5, menunjukan bahwa semua petani responden pernah mengikuti pendidikan formal, sebagian besar petani responden pendidikannya adalah SD yaitu sebanyak 5 petani atau $50 \%$ dari jumlah responden selanjutnya, 30\% petani atau 3 petani dari seluruh responden adalah SMU/sederajat, dan 2 petani atau 20\% dari jumlah responden berpendidikan SMP. Hal ini menunjukan tingkat pendidikan petani responden relatif rendah.

\section{Luas lahan dan komoditi yang di tanam}

Luas lahan yang dimiliki petani dan tingkat kesuburan tanah akan berpengaruh kepada pendapatan petani. Dimana semakin luas lahan yang dimiliki maka jumlah produksi pun akan meningkat, namun ini semua harus di tunjang dengan harga pasar. Luas lahan Holtikultura dari petani responden di Kecamatan Sorong Timur dapat dilihat pada Tabel 7.

Dari tabel 6, menunjukan luas lahan terbesar adalah <1,5-2 Ha yaitu sebanyak 6 petani atau $60 \%$ dari jumlah responden, dan 6 petani ini mengunakan saluran pemasaran pertama. Petani yang memiliki luas lahan $>3$ sebanyak 4 petani atau $40 \%$ dari jumlah seluruh responden, 4 petani tersebut menggunakan saluran yang kedua.

Tabel 6. Luas Lahan dan Jenis Tanaman yang di Tanam oleh responden di Kelurahan Klawalu dan Klamana, Kecamatan Sorong Timur

\begin{tabular}{|c|c|c|c|}
\hline $\begin{array}{l}\text { Luas Lahan } \\
\text { (Ha) }\end{array}$ & $\begin{array}{l}\text { Jumlah Petani } \\
\text { (Orang) }\end{array}$ & $\begin{array}{c}\text { Presentase } \\
(\%)\end{array}$ & $\begin{array}{l}\text { Jenis Komoditi Yang di } \\
\text { tanam }\end{array}$ \\
\hline$<1,5-2$ & 6 & $60 \%$ & $\begin{array}{l}\text { Holtikultura : Kangkung, } \\
\text { sawi, bayam, pepaya, } \\
\text { Umbian : ubi kayu, ubi jalar } \\
\text { dan Pangan Jagung } \\
\text { Kacangan : kacang keledai, } \\
\text { kacang tanah }\end{array}$ \\
\hline$>3$ & 4 & 40 & $\begin{array}{l}\text { Holtikultura : Buncis, } \\
\text { kacang Panjang, terong, } \\
\text { nangka, kangkung cabut, } \\
\text { Umbian : ubi kayu, Ubi Jalar } \\
\text { Kacangan : kacang tanah }\end{array}$ \\
\hline Jumlah & 10 & 100 & \\
\hline
\end{tabular}

Sumber : Data Primer dikumpulkan dan diolah oleh Margareta Arne, 2014 
Tabel 7. Jenis Komoditi Per Kelurahan 2012

\begin{tabular}{|c|c|c|c|}
\hline No & Kelurahan & Sub sektor & Pilihan Jenis Komoditi \\
\hline 1 & Klasaman & Tanaman Pangan & $\begin{array}{l}\text { Jagung, ubi kayu, ubi jalar, keladi, sayuran, } \\
\text { buah, sapi, babi, kambing dan ayam }\end{array}$ \\
\hline 2 & Klawuyuk & Tanaman Pangan & $\begin{array}{l}\text { Jagung, sayuran, sapi, } \\
\text { babi, kambing, dan ayam }\end{array}$ \\
\hline 3 & Klamana & Tanaman Pangan & $\begin{array}{l}\text { Jagung, ubi kayu, ubi jalar, } \\
\text { pisang,sayuran,sapi, kambing dan ayam }\end{array}$ \\
\hline 4 & Klawalu & Tanaman Pangan & Jagung, sayur, sapi, kambing dan ayam \\
\hline 5 & Giwu & Tanaman Pangan & Jagung, sayur, sapi, kambing dan ayam \\
\hline 6 & Klablim & Tanaman Pangan & $\begin{array}{l}\text { Jagung, ubi kayu, ubi jalar, keladi, sayuran, } \\
\text { buah, sapi, babi, kambing dan ayam }\end{array}$ \\
\hline 7 & Kalasuat & Tanman Pangan & Jagung, sayuran, sapi, babi danayam \\
\hline
\end{tabular}

Sumber : Dinas Pertanian Kota Sorong

\section{Jenis Komoditi Perkelurahan}

Komoditi pertanian yang dapat dikembangkan di wilayah Distrik Sorong Timur, berdasarkan data yang ada maka dapat disusun pilihan komoditas yang dapat dikembangkan pada setiap kelurahan di Distrik Sorong Timur sebagai berikut :

Tabel 7 menunjukan rata - rata hasil pertanian atau komoditi yang di kembangkan atau dihasilkan di kecamatan Sorong Timur yang tersebar di beberapa kelurahan yang ada hampir semua dapat menghasilkan beberapa komoditi yang sama. Keterangan : sayuran yang di kembangkan : kangkung, bayam, sawi, terong, kacang panjang, timun dan cabe.

\section{Potensi Pertanian}

Potensi pertanian tanaman pangan dan hortikultura, luas tanaman jagung, umbi-umbian dan kacang tanah seluas $150 \mathrm{Ha}$. Komoditi pertanian tanaman pangan dan hortikultura di Distrik Sorong Timur tersebar di Wilayah Kelurahan Klasaman, Klablim, Klamana dan sebagian di Kelurahan Kalasuat. Komoditi tanaman pangan adalah jagung, ubi kayu, ubi jalar dan keladi.
Dari Tabel 8 dapat dilihat bahwa luas panen berupa jagung, ubi kayu, ubi jalar dan kacang tanah, yang ada di Kecamatan Sorong Timur produksinya sangat bervariasi dimana komoditas tanaman pangan yang mempunyai kontribusi besar atau produksi tertinggi adalah jagung dengan luas panen 80 ha dan capaian produksi 154 ton tahun 2012 atau mengalami peningkatan dimana hal ini didukung dengan kondisi wilayahnya dengan hamparan lahan kering yang cukup luas menjadi peluang bagi petani jagung untuk terus memanfaatkan dan memproduksi jagung untuk memenuhi kebutuhannya.

Komoditas hortikultura yang dominan di Distrik Sorong Timur adalah kangkung, bayam, sawi, kacang panjang, ketimun dan lainnya.

Dapat dilihat pada tabel 9 diatas, produksi tanaman sayuran berupa: kangkung, kacang panjang, bayam, sawi di kecamatan Sorong Timur produksinya sangat bervariasi dimana komoditas tanaman sayuran mempunyai kontribusi besar atau produksi tertinggi adalah kangkung 96 ton. 
Tabel 8. Luas Panen dan Produksi Tanaman di Distrik Sorong Timur 2012

\begin{tabular}{llllllllc}
\hline Kelurahan & $\begin{array}{l}\text { Jagung } \\
\text { LP Ha }\end{array}$ & $\begin{array}{l}\text { PR } \\
\text { TN }\end{array}$ & $\begin{array}{l}\text { Kayu } \\
\text { LP Ha }\end{array}$ & $\begin{array}{l}\text { PR } \\
\text { TN }\end{array}$ & $\begin{array}{l}\text { Ubi } \\
\text { LP } \\
\text { Ha }\end{array}$ & $\begin{array}{l}\text { PR } \\
\text { TN }\end{array}$ & LP Ha & PR TN \\
\hline Klasaman & 10 & 20 & 10 & 29 & 5 & 5 & 4 & 7 \\
Klawuyuk & 15 & 30 & 5 & 15 & - & - & - & - \\
Klamana & 15 & 30 & 5 & 15 & 4 & 4 & - & - \\
Klawalu & 5 & 10 & - & - & - & - & - & - \\
Giwu & 5 & 10 & - & 10 & - & - & - & - \\
Klablim & 20 & 40 & 7 & 17 & 2 & 2 & - & - \\
Kalasuat & 10 & 24 & 5 & 10 & 3 & 3 & - & - \\
\hline Jumlah & $\mathbf{8 0}$ & $\mathbf{1 5 4}$ & $\mathbf{3 7}$ & $\mathbf{9 3}$ & $\mathbf{1 4}$ & $\mathbf{1 4}$ & $\mathbf{4}$ & $\mathbf{7}$ \\
\hline
\end{tabular}

Sumber : Dinas Pertanian Kota Sorong 2012

Tabel 9. Produksi Tanaman Sayuran di Distrik Sorong Timur Tahun 2012

\begin{tabular}{lllllll}
\hline No & Kelurahan & \multicolumn{5}{c}{$\begin{array}{l}\text { Produksi } \\
\text { sayuran }\end{array}$} \\
\hline & Kangkung & $\begin{array}{l}\text { Kacang } \\
\text { Panjang }\end{array}$ & Bayam & Sawi & lain \\
1 & Klasaman & 13 & 12 & 10 & 10 & 23 \\
2 & Klawuyuk & 12 & 13 & 5 & 6 & 35 \\
3 & Klamana & 20 & 19 & 10 & 10 & 45 \\
4 & Klawalu & 10 & 9 & - & - & 30 \\
5 & Giwu & 5 & 5 & - & 5 & 35 \\
6 & Klablim & 20 & 19 & 10 & 5 & 60 \\
7 & Klasuat & 16 & 15 & - & 4 & 45 \\
& Jumlah & $\mathbf{9 6}$ & $\mathbf{9 2}$ & $\mathbf{3 5}$ & $\mathbf{4 0}$ & $\mathbf{2 4 0}$ \\
\hline
\end{tabular}

Sumber : Dinas Pertanian Kota Sorong 2012.

Keterangan : Cabe, Terong, Pepaya, Nangka, dan Singkong

\section{Peternakan}

Perkembangan populasi dan produksi ternak di Distrik Sorong Timur dipengaruhi beberapa faktor antara lain : Angka Kelahiran dan Tingkat Kematian, Jumlah Pemasukan ternak dari luar dan pemotongan. Populasi ternak di Distrik Sorong Timur dilihat pada tabel 10 .

Dari Tabel 10 dapat dilihat bahwa ternak terbanyak yaitu masih didominasi oleh ternak babi dengan jumlah total 1.039 ekor, sebagian besar masyarakat
Kecamatan Sorong Timur memelihara babi, karena selain untuk memenuhi kebetuhan akan ikan, babi juga dianggap menjadi alternatif yang cepat untuk menghasilkan uang karena kebutuhan akan babi dipasaran setiap harinya terus meningkat. Sehingga apabila ada keperluan mendadak dari masyarakat yang memelihara babi tersebut mereka langsung membawanya untuk dijual dipasaran. Pemeliharaan ternak unggas di semua Kelurahan di Distrik Sorong Timur ada, hanya tingkat populasinya berbeda. 


\begin{tabular}{lllll}
\multicolumn{6}{l}{ Tabel 10. Populasi Ternak Besar dan Kecil di Distrik Sorong Timur } & Tahun & $\mathbf{2 0 1 2}$ \\
\hline No & Kelurahan & \multicolumn{4}{l}{ Populasi } \\
\hline & Sapi & Babi & Kambing \\
1 & Klasaman & 250 & 50 & 100 \\
2 & Klawuyuk & 160 & - & 65 \\
3 & Klawana & 72 & 150 & 110 \\
4 & Giwu & 90 & 350 & 50 \\
5 & Klablim & 200 & 50 & - \\
6 & Klasuat & 97 & 400 & 50 \\
7 & Jumlah & $\mathbf{9 7 3}$ & 39 & - \\
& & $\mathbf{1 . 0 3 9}$ & $\mathbf{3 7 5}$ \\
\hline
\end{tabular}

Sumber : Dinas Pertanian Kota Sorong 2012.

Tabel 11. Populasi Ternak Unggas di Distrik Sorong Timur Tahun 2012

\begin{tabular}{|c|c|c|c|c|c|c|}
\hline No & Kelurahan & & $\begin{array}{l}\text { Produksi } \\
\text { Ternak } \\
\text { Unggas }\end{array}$ & & & \\
\hline & & $\begin{array}{l}\text { Ayam } \\
\text { Buras }\end{array}$ & Ayam Telur & $\begin{array}{l}\text { Ayam } \\
\text { Daging }\end{array}$ & Itik & Entok \\
\hline 1 & Klasaman & 2.100 & - & 164.929 & 100 & 20 \\
\hline 2 & Klawuyuk & 1.150 & - & - & 49 & - \\
\hline 3 & Klamana & 1.100 & - & 100.000 & - & - \\
\hline 4 & Klawalu & 2.050 & - & - & - & - \\
\hline 5 & Giwu & 1.000 & - & - & - & - \\
\hline 6 & Klablim & 1.093 & - & 100.000 & 100 & 29 \\
\hline \multirow[t]{2}{*}{7} & Klasuat & 1.100 & - & - & - & - \\
\hline & Jumlah & 9.693 & - & 364.929 & 249 & 49 \\
\hline
\end{tabular}

Sumber : Dinas Pertanian Kota Sorong 2012.

Tabel 12. Tingkat Pendidikan Kecamatan Sorong Timur

\begin{tabular}{llll}
\hline No & Tingkat Pendidikan & Jumlah & Presentase \\
\hline 1 & Belum sekolah & 9,937 & 13,39 \\
2 & Tidak Tamat sekolah & 4,232 & 8,26 \\
3 & Tamat SD Sederajat & 9,030 & 17,35 \\
4 & Tamat SMP Sederajat & 11,521 & 22,21 \\
5 & Tamat SMU Sederajat & 7,771 & 14,35 \\
6 & Tamat perguruan Tinggi & 52 & 15,78 \\
7 & Buta Akrasa & 27 & 0,05 \\
8 & Lainnya & 4,647 & 8,82 \\
\hline & Jumlah & $\mathbf{4 3 , 3 4 7}$ & $\mathbf{1 0 0}$ \\
\hline
\end{tabular}

Sumber : Kantor Kecamatan Sorong Timur 2012

Tabel 12 menunjukan bahwa penduduk di Kecamatan Sorong Timur sebagian besar adalah belum sekolah dengan jumlah 9,937 dengan mencapai persentase adalah 13,39. Hal ini menunjukan cara berfikir dan bersaing masih rendah. 


\section{Kondisi Fisik Lingkungan}

\section{Sumber Daya Alam}

Potensi sumber daya lahan Kecamatan Sorong Timur yang potensial untuk pengembangan usaha pertanian holtikultura, lahan perkebunan, peternakan dan perikanan darat . Adapun penggunaan lahan sebagai hutan ( hutan Rakyat atau hutan lindung ) dengan luas $147 \mathrm{Ha}$, sungai dan rawa $\pm 70 \mathrm{Ha}$, pemukiman dan infrastruktur \pm $5.000 \mathrm{Ha}$, dan lahan pertanian, perkebunan, lahan pengembangan peternakan dan perikanan darat \pm $9.000 \mathrm{Ha}$.

\section{Sumber Daya Manusia}

Prioritas pembangunan SDM di kecamatan Sorong Timur ini sangat dibutuhkan karena kurangnya tenaga kerja dan para ahli dalam pengembangan pertanian dan perdagan, maka pengembangan sumber daya manusia diarahkan agar utama maju dan mandiri serta mampu menunjang pencapaian sasaran pembangunan yang di tetapkan. Penerapan agribisnis dan agroindustri diarahkan untuk memberi nilai tambah dari komoditas yang dihasilkan oleh petani melalui upaya pengolahan hasil, pemasaran hasil dalam dan luar negeri serta pemilihan jenis komoditas yang menguntungkan dan meningkatkan pendapatan daerah.

Lingkungan internal adalah berbagai hal yang terkait langsung dengan kegiatan pengembangan kawasan perdesaan kecamatan Sorong Timur yang mempengaruhi setiap program dan kebijakan yang ada. Hasil dari lingkungan internal ini untuk mengidentifikasi dan menentukan kekuatan dan kelemahan dalam pengembangan kawasan perdesaan. Kekuatan atau keunggulan dalam pengembangan perdesaan merupakan segala sumber daya dan potensi yang dimiliki oleh kecamtan Sorong Timur yang berkaitan dengan pengembangan kawasan perdesaan yang berbasis agribisnis. Sedangkan kelemahan merupakan bagian yang memungkinkan sebagai penghambat dalam pengembangan kawasan perdesaan yang ada di Kecamatan itu sendiri.

\section{Kondisi Penduduk: Jumlah Penduduk}

Masyarakat kecamatan Sorong Timur bersifat heterogen terdiri atas etnis Papua dan pendatang dari luar Papua. Jumlah penduduk 30.032 jiwa dari Tahun 2013 tercatat. Sekitar 48\% dari total penduduk laki-laki dan sisanya adalah perempuan $52 \%$.

\section{Pelayanan Pablik: Sarana dan Prasarana}

Prasarana dan sarana sosial yang tersedia seperti fasilitas pendidikan sekolah dasar sebanyak 5 unit, sekolah lanjutan pertama 3 unit, sekolah lanjutan atas 5 unit, dan akademik perguruan tinggi 2 unit. Sedang fasilitas kesehatan seperti rumah sakit sebanyak 1 unit, puskesmas 3 unit, toko obat 9 unit, toko obat pertanian 1 unit. Penunjang agribisnis Bank, PLN dan sarana untuk keagamaan adalah mesjid 9 unit, gereja 8 unit, wihara 3 unit, pura 6 unit bahwa dengan ketersedian fasilitas dapat meningkatkan kualitas sember daya manusia dan kepercayaan untuk sekaligus dapat berperan secara aktif di dalam proses pembangunan di kecamatan Sorong Timur.

\section{Transportasi antar wilayah}

Sarana dan prasarana potensial di dalam menunjang pembangunan atau pengembangan kawasan perdesaan di Kecamatan Sorong Timur antara lain : prasarana transportasi jalan yang di tempuh dari kota ke kecamatan tersebut baik kendaraan beroda dua atau beroda empat untuk mengankut hasil- hasil pertanian.

\section{Bisnis dan Lapangan Usaha}

\section{Perindustrian}

Kecamatan Sorong Timur yang merupakan daerah berkembang tentunya usaha baru giat dibuka guna pemenuhan kebutuhan masyarakat yang semakin beragam. Kemudian untuk usaha industri proporsi terbanyak tersebar diwilayah Kecamatan Sorong Tiumur Rincian industri dapat dilihat pada Tabel. Pada khususnya industri yang banyak berkembang di masyarakat adalah industri kecil dan industri rumah tangga, seperti industri pembuatan bengkel serta meubel kayu. 
Tabel 13. Industri di Kecamatan Sorong Timur Kota Sorong menurut Jenis Industri Tahun 2012

\begin{tabular}{|c|c|c|c|c|c|}
\hline & & $\begin{array}{l}\text { Banyaknya } \\
\text { Industri }\end{array}$ & & & \\
\hline No & Jenis Usaha & $\begin{array}{l}\text { Banyak } \\
\text { Usaha }\end{array}$ & Tenaga Kerja & Produksi/Thn & Investasi \\
\hline 1 & Mebel kayu & 20 & 9 & $150,000,00$ & $750,000,0$ \\
\hline 2 & Sol sepatu & 15 & 3 & $10,000,00$ & - \\
\hline 3 & Penjahit pakian & 20 & 5 & $15,000,00$ & - \\
\hline 4 & Jok kursi & 11 & 8 & $20,000,00$ & - \\
\hline 5 & Sablon & 12 & 6 & $11,000,00$ & - \\
\hline 6 & salon kecantikan & 15 & 7 & $9,000,00$ & - \\
\hline 7 & Cuci kendaraan & 17 & 4 & $5,000,00$ & - \\
\hline 8 & Kerajinan emas & 11 & 5 & $120,000,00$ & $200,000,0$ \\
\hline 9 & Foto studio & 10 & 5 & $50,000,00$ & $230,000,0$ \\
\hline 10 & Foto copy & 7 & 3 & $20,000,00$ & $250,000,0$ \\
\hline \multirow[t]{3}{*}{11} & Bengkel & 13 & 7 & $60,000,00$ & $50,000,0$ \\
\hline & Kendaraan & & & & \\
\hline & Jumlah & 151 & 62 & $470,000,00$ & $148,000,0$ \\
\hline
\end{tabular}

Sumber : Perindustrian Kota Sorong 2012

Tabel 13 di atas menunjukan Jumlah industri atau lapangan usaha di Kecamatan Sorong Timur Kota Sorong pada tahun 2012 yang lebih besar adalah meubel kayu 15 jenis usaha dengan tenaga kerja 9 orang, produksi rata-rata 150 per Tahun jumlah unit usaha paling kecil di Kelurahan Klasaman Foto copy 7 unit dengan jumlah tenaga kerja 3 orang sedangkan jumlah produksi 20 juta per Tahun. Tabel 14 dmenunjukan golongan perusahaan menerut permodalan perdagangan besar, menengah, kecil, mikro dan golongan usaha menurut hukum persero terbatas, koperasi, $\mathrm{Cv}$, perusahaan perorangan yang ada di Kecamatan Sorong Timur pada tahun 2008-2012.
Deskripsi lebih dalam tentang kontribusi Kecamatan Sorong Timur dapat ditunjukkan dengan presentase tiap lapangan usaha terhadap PDRB Indonesia. Secara umum, tiap lapangan usaha memiliki kontribusi tidak lebih dari $1 \%$. Kontribusi terbesar kepada Indonesia adalah pada sektor primer sebesar $1,088 \%$, yaitu dari perikanan dan pertambangan. Kekayaan alam yang berlimpah terutama di sektor primer. Apabila ditinjau dari pendapatan per kapita, memiliki pendapatan per kapita pada tahun 2005 sebesar Rp 12.296.072, menempati peringkat provinsi, meningkat $177 \%$ dibandingkan tahun 2000 yaitu Rp. 6.944.000. 
Tabel 14. Jumlah Perusahaan menurut Permodalan dan Hukum di Kecamatan Sorong Timur Tahun 2008-2012

\begin{tabular}{llllll}
\hline Uraian & 2008 & 2009 & 2010 & 2011 & 2012 \\
\hline 1 & $\mathbf{2}$ & $\mathbf{3}$ & $\mathbf{4}$ & $\mathbf{5}$ & $\mathbf{6}$ \\
\hline
\end{tabular}

I. Golongan perusahan menurut permodalan

1. Perdagangan besar 34

2. Perdagangan menengah 32

3. Perdagangan kecil

4. Perdagangan 100 $00 \quad 88$

30

18

88

mikro

II. Golongan Usaha

Menurut Hukum

1. Perseroan

Terbatas

2. Koperasi

3. C.V

4. Perusahaan perorangan

\section{1}

2

45

30

\begin{tabular}{ll}
32 & 18 \\
00 & 88 \\
\hline
\end{tabular}

36

50

115

80

40
1

20

58

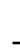

Sumber : perindustrian Kota Sorong 2012

Tabel 15. Persentase PDRB Kota Sorong terhadap PDRB Indonesia Tahun 2012 Dirinci Per Lapangan Usaha

\begin{tabular}{llll} 
Lapangan Usaha & $\begin{array}{l}\text { PDRB Kota } \\
\text { Sorong }(\mathbf{R P})\end{array}$ & $\begin{array}{l}\text { PDRB Indonesia } \\
\text { (Juta Rupiah) }\end{array}$ & $\begin{array}{c}\text { Kontribusi } \\
(\mathbf{\%})\end{array}$ \\
\hline pertanian & $2.152 .984,76$ & $363.928,80$ & 0,592 \\
\hline Pertambangan & $1.528 .370,11$ & $308.339,10$ & 0,496 \\
\hline Industri pengolahan & $1.580 .176,29$ & $771.724,00$ & 0,206 \\
\hline Listrik, gas, dan air & $39.717,67$ & $26.693,50$ & 0,149 \\
\hline bangunan & $565.568,00$ & $195.775,00$ & 0,289 \\
\hline Perdagangan & $769.089,13$ & $430.154,20$ & 0,179 \\
\hline Angkutan dan Komunikasi & $508.223,79$ & $180.969,70$ & 0,281 \\
\hline Keuangan, persewaan dan jasa & $137.037,89$ & $230.587,20$ & 0.059 \\
\hline Jasa-jas & & & \\
\hline \multicolumn{1}{c}{ Total } & $\mathbf{6 2 2 . 0 3 7 , 2 7}$ & $276.879,00$ & 0,225 \\
\hline Sumber: BPs Kota Sorong & $\mathbf{7 . 9 0 3 . 2 0 1 , 9 1}$ & $\mathbf{2 . 7 8 5 . 0 5 0 , 0 0}$ & $\mathbf{0 , 2 8 4}$
\end{tabular}


Tabel 16. PDRB Kota Sorong Sektor Pertanian

\begin{tabular}{llllc}
\hline No & Lapangan Usaha Sektor & & \multicolumn{2}{l}{ Jumlah Kontribusi Pertahunan } \\
& Pertanian & $\mathbf{2 0 1 0}$ & $\mathbf{2 0 1 1}$ & $\mathbf{2 0 1 2}$ \\
& & $31.679,29$ & $35.435,71$ & $36.885,76$ \\
\hline 1 & $\begin{array}{l}\text { Tanaman } \\
\text { Bahan Makanan }\end{array}$ & $1.373,07$ & $1.496,87$ & $1.639,66$ \\
\hline 2 & Tanaman Perkebunan & $3.207,31$ & $3.629,22$ & $4.109,28$ \\
\hline 3 & Peternakan dan Hasilnya & $76.583,24$ & $89.995,84$ & $96.401,67$ \\
\hline 4 & Kehutanan & $27.766,42$ & $29.271,28$ & $31.579,08$ \\
\hline 5 & Perikanan & $\mathbf{1 4 0 . 6 0 0 , 3 3}$ & $\mathbf{1 5 9 . 6 0 0 , 3 3}$ & $\mathbf{1 7 0 . 5 8 5 , 4 5}$ \\
\hline & Jumlah & & &
\end{tabular}

Sumber : BPS Kota Sorong 2012

Tabel 16 menunjukkan bahwa lapangan usaha bahan makanan secara konsisten menjadi peringkat kedua setelah kehutanan. Dengan melihat realita dimana daerah berpenghuni petani maka dapat disimpulkan bahwa tingkat produktivitas bahan makanan sebetulnya sangat tinggi. Hanya beroperasi di 7 kelurahan dan 14 kecamatan di Kota Sorong tetapi bisa menyumbangkan $21 \%$ lebih PDRB di sektor pertanian.

\section{KESIMPULAN}

\section{Kesimpulan}

Berdasarkan penelitian yang telah dilakukan, diperoleh beberapa kesimpulan yaitu :

1. Luas lahan pertanian dengan luas $\pm 9000 \mathrm{Ha}$, luas lahan basah atau sungai, rawa \pm 5000 $\mathrm{Ha}$, peternakan $121 \mathrm{Ha}$, industri kecil $2 \mathrm{Ha}$. Komoditi pertanian luas panen holtikultura, jagung, ubi kayu, ubi jalar, kacang tanah, keladi $84 \mathrm{Ha}$, komoditi pertanian dengan produksi rata - rata 1967 per ton .

2. Lapangan usaha menurut jenis terdiri dari : Mebel kayu produksi atau pendapatan paling tinggi 150,000,00 per Tahun, kerajinan Emas 120,000,00 produksi per tahun. Adapun lapangan usaha menurut golongan perusahan, golongan usaha menurut hukum dan lapangan usaha pertanian.

3. Faktor pendukung bisnis terdiri dari : KUD, Toko obat, jalan yang memadai, alat penerangan, pasar, bank untuk kredit.

4. Faktor penghambat terdiri dari : motivasi petani berkurang, tenaga ahli kurang, pengolahan tidak tersedia.

\section{Saran}

1. Untuk upaya peningkatan agribisnis perdesaan di Kecamatan Sorong Timur, diperlukan kerja sama yang baik antar semua pihak yang terkait dalam kegiatan agribisnis.

2. Bagi pemerintah agar dapat memperbaiki infrastruktur jalan desa, menyediakan sarana teknologi pengolahan hasil produksi pertanian, memfasilitasi pendidikan dan pelatihan kepada para petani di Kecamatan demi terwujudnya tenaga-tenaga yang ahli dalam bidang agribisnis untuk mengatasi kelemahan.

\section{DAFTAR PUSTAKA}

Adisasmita, Raharjo. 2006. Pengembangan Wilayah Konsep dan Teori. Graha Ilmu. Yogyakarta

Arsyad, A., 1985. Pengantar Perencanaan dan dan Pengembangan Ekonomi Daerah. BPFEUGM. Yogyakarta

Budiharsono, S., 2002. Teknik Analisis Pembangunaan Wilayah Pesisir dan Lautan. Penerbit P.T Pradya Paramita. Jakarta

Badan Pusat Statistik, 2012. Kota Sorong dalam Angka. Kecamatan Sorong Timur 2012.

Bahri, E. 2009 Alternatif Strategi Pembangunan Sosial. Graha Ilmu. 
Direktorat Jendral Cipta Karya. 2007. Paduan Penyusunan Rencana Program Kawasan Terpilih Pusat Pengembangan Perdesaan. Departemen Pekerjaan Umum.

Jakarta Glason. 1990. Pengantar Perencanaan Regional, Terjemahan P. Sitohay. Penerbit LPFE, Universitas Indonesia. Jakarta

Indratno, I., 2006. Pengembangan Pusat Pertumbuhan dalam Rangka Pengembangan Kawasan Perdesaan. Fakultas Teknik Universitas Islam. Bandung.

Nasution, Z. 2007. Pengembangan Wilayah, Pengenalan Teori. PT. Raja Grafindo Persada. Jakarta

Rahardjo, A., 2007. Pembangunaan Kawasan dan Tata Ruang. Makasar
Seafulhakim, ddk. 2002. Studi Penyusunan Wilayah Pengembangan Strategis. IPB dan Bapenas. Bogor.

Soekartawi. 2001. Agribisnis (Teori dan Aplikasi) . PT Raja Grafindo Persada. Jakarta.

Tarigan, R. 2010. Perencanaan Pengembangan Wilayah. Bumi Aksara. Jakarja.

Triutomo, S. 2001. Pengembangan Wilayah melalui pembentukan kawasan Pengembangan Ekonomi Terpadu. Badan Pengkaji dan Penerapan Teknologi. Jakarta.

Undang-Undang No. 26 Tahun 2007. Tentang Penataan Ruang dan Bapenas Tahun 2005.

Undang- Undang N0. 51 Tahun 2007. Tentang Penataan ruang. 